\title{
Effects of ambient air pollution on allergic rhinitis among preschool children in Changsha, China
}

\author{
LU Chan ${ }^{1}$, DENG QiHong ${ }^{1 *}$, OU CuiYun ${ }^{1}$, LIU WeiWei ${ }^{1} \&$ SUNDELL Jan ${ }^{2}$ \\ ${ }^{1}$ School of Energy Science and Engineering, Central South University, Changsha 410083, China; \\ ${ }^{2}$ Department of Buiding Science, Tsinghua University, Beijing 100084, China
}

Received December 6, 2012; accepted January 18, 2013; published online May 15, 2013

\begin{abstract}
Prevalence of allergic rhinitis has rapidly increased among Chinese children, but the reasons are unclear. Recent findings have suggested that exposure to outdoor air pollutants may increase the risk of allergic rhinitis, but the results were inconsistent. This study further investigated the effect of outdoor air pollutants on allergic rhinitis among preschool children. A standardized questionnaire on health, home and environmental factors was conducted for 4988 children aged 1-8 in the city of Changsha, and the concentrations of $\mathrm{PM}_{10}$ (particle diameter $\leqslant 10 \mu \mathrm{m}$ ), sulfur dioxide $\left(\mathrm{SO}_{2}\right)$ and nitrogen dioxide $\left(\mathrm{NO}_{2}\right)$ during 2006-2011 were acquired from the official web of Changsha Environmental Protection Agency. Results showed that the prevalence of children's doctor diagnosed rhinitis was $8.4 \%$ (95\% confidence interval [CI] 7.0\%-10.0\%). It was found that the prevalence of rhinitis was not associated with site-specific background concentrations of air pollutants, but significantly positively correlated with age-related accumulative personal exposure of $\mathrm{PM}_{10}, \mathrm{SO}_{2}$ and $\mathrm{NO}_{2}$. We conclude that age-related accumulative personal exposure to ambient air pollution may play an important role in the development of rhinitis.
\end{abstract}

air pollutants, diagnosed rhinitis, background concentration, logistic regression, personal exposure

Citation: $\quad$ Lu C, Deng Q H, Ou C Y, et al. Effects of ambient air pollution on allergic rhinitis among preschool children in Changsha, China. Chin Sci Bull, 2013, 58: 4252-4258, doi: 10.1007/s11434-013-5725-2

The prevalence of allergic diseases including allergic rhinitis (AR) largely increased not only in developed countries [1,2] but also in developing countries $[3,4]$ in the recent decades. China, as the largest developing country, has experienced a rapid increasing in the prevalence of AR. In Hong Kong, the prevalence of AR among children aged 6-7 years has been reported to increase from 1995 to 2001 [3]. The International Study of Asthma and Allergies in Childhood (ISAAC) estimated the prevalence in five cities of Mainland China (Beijing, Chongqing, Guangzhou, Shanghai and Urumqi) and Hong Kong was respectively as high as 5\%-10\% and 24\% among children aged 13-14 in 1998 [4]. Most studies evaluated the prevalence of AR for older children and/or adults, only a few epidemiological studies on the prevalence of $\mathrm{AR}$ in younger children [5]. However, the knowledge

*Corresponding author (email: qhdeng@ csu.edu.cn) about the prevalence of the allergic diseases in the earlier stages of childhood is of greater significance for the following development of the diseases.

Exposure to ambient air pollutants has been suggested to increase the risk of $\mathrm{AR}$ in children, but the evidence was still weak and inconclusive [6-13]. Some studies have suggested that exposure to outdoor air pollutants, especially for traffic-related pollutant, may increase the risk of allergic rhinitis in children [6-8]. These studies mainly focused on the background air pollution. However, the impact of air pollutants on health is closely related to the extent of individual exposure, which includes not only exposure concentration but also exposure time [14]. Although numerous studies indicated that the airway health could be caused by short-term exposure to air pollutants at high concentration, long-term exposure to air pollutants at low concentrations may also induce an equivalent effect, which suggests an 
accumulative effect of air pollution exposure on health [15-19]. Therefore, the effect of the timing of exposure to air pollutants or the accumulative exposure to air pollutants on childhood allergic rhinitis needs to be further investigated.

China has witnessed worsening air quality during the past two decades, due to the rapid urbanization, economic growth, industrial development, and increasing amount of vehicles [20]. Although municipal government adopted a series of measures including reduction and control of factory pollution, the air quality is still serious in some cities [21]. For example, in Changsha, the capital city of Hunan province, the annual level of $\mathrm{PM}_{10}$, the major component of air pollution, continuously exceeded the National Ambient Air Quality Standard (NAAQS) $\left(100 \mu \mathrm{g} / \mathrm{m}^{3}\right)$ during the period from 2003 to 2007 (http://www.csqx.com/). The effect of high air pollution in China on the children's allergic diseases is lack.

In the present study, we assume that long-term exposure to high concentration of ambient air pollutants may increase the risk of children's AR. Based on above hypothesis, the objectives of this study are to assess the different prevalence of allergic rhinitis in children aged 3-6 in Changsha, and to investigate and compare the effect of site-specific average background and age-related personal accumulative exposure to $\mathrm{PM}_{10}, \mathrm{SO}_{2}$ and $\mathrm{NO}_{2}$ on children's diagnosed allergic rhinitis.

\section{Methods}

\subsection{Questionnaire and study population}

The questionnaire is basically the same as used in parallel studies in Sweden, Bulgaria and many other countries [22,23], with small changes taking into consideration of the specific Chinese housing and cultural characteristics. The questionnaire surveys the life style of residents, home environment and the health status of children and family members. The outcome of interest in the present study was childhood diagnosed allergic rhinitis, which was defined on the basis of the answers to the question: "Has a physician ever diagnosed your child as having allergic rhinitis?". Information on potential confounders was also obtained from the questionnaire. The personal covariates in the present analyses included age, gender, family atopy, environmental tobacco smoke (ETS), breast-feeding, cockroaches noted, flooding or water damage and visible mould. The definition in detail for each covariate was described in Table 1. Children aged $1-8$ in 23 kindergartens located in 4 districts (Kaifu, Yuhua, Yuelu and Furong) of Changsha were investigated (Figure 1). The 4988 questionnaires were randomly distributed during the period from November 2011 to January 2012. The questionnaires were firstly distributed to the kindergartens with the permission of their principals, then the trained teachers working at each kindergarten handed out these questionnaires to the parents, and finally the completed questionnaires filled by the parents were returned back within one
Table 1 Definition of covariates applied in the questionnaire

\begin{tabular}{ll}
\hline \multicolumn{1}{c}{ Determinant } & \multicolumn{1}{c}{ Definition } \\
\hline Parental atopy & $\begin{array}{c}\text { Farther or mother of the index child ever having di- } \\
\text { agnosed asthma, allergic rhinitis, or atopic eczema } \\
\text { Home environmental tobacco smoke, cigarette } \\
\text { smoking by father, mother, grandparents or other } \\
\text { people who live with the children } \\
\text { The duration of breast-feeding for the child: No } \\
\text { breast-feeding, <1 month, 1-2 months, 3-6 months, } \\
\text { and }>6 \text { months } \\
\text { Breast-feeding } \\
\text { Cotice cockroach always/frequently/sometimes in } \\
\text { the house } \\
\text { Water damage }\end{array} \quad \begin{array}{l}\text { Flooding or other water damage in the house ever } \\
\text { Noticed any visible mildew or mould in the floor, } \\
\text { 2wall or ceiling of child's room }\end{array}$ \\
\hline
\end{tabular}

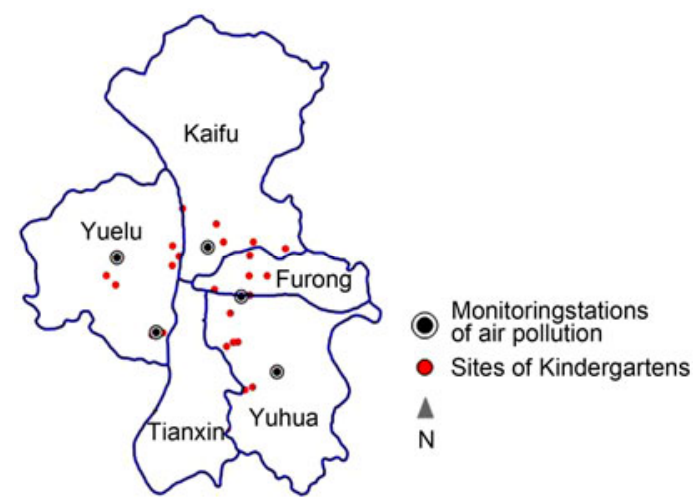

Figure 1 (Color online) Distributions of kindergartens and air pollution monitoring stations in Changsha.

week. The data of the questionnaires were collected in a database, and the data for the children aged 3-6 were used in this study.

\subsection{Exposure assessment}

Routinely monitored data for $\mathrm{PM}_{10}$ (particles with an aerodynamic diameter of $10 \mu \mathrm{m}$ or less), sulphur dioxide $\left(\mathrm{SO}_{2}\right)$ and nitrogen dioxide $\left(\mathrm{NO}_{2}\right)$ are available from Changsha Environmental Protection Agency. Daily concentrations of each pollutant were measured continuously and reported by the website of Changsha Common Meteorologic Information Service (http://www.csqx.com/).

In the present study, background concentrations of air pollutants at different monitoring sites were calculated by the annual average concentrations of $\mathrm{PM}_{10}, \mathrm{SO}_{2}$ and $\mathrm{NO}_{2}$ during the period 2007-2011. The annual value from the closest local monitoring station was used to all children in that district. For age-related personal accumulative exposure, the values were calculated by the sum of previous annual concentrations of each pollutant and as an example, the personal accumulative exposure for children aged 3 was the sum of annual concentrations of air pollutants over the past three years $(2009,2010$ and 2011) [24]. 


\subsection{Statistical methods}

The association between air pollutants and allergic rhinitis in children was analyzed by multivariate logistic regression models, adjusting for confounding factors. The odds ratio (OR) was used as a measure of the relation between exposure to air pollution and the prevalence of allergic rhinitis in childhood. The results were showed by adjusted odds ratios with $95 \%$ confidence interval (CI). A $P$-value $<0.05$ indicates statistical significance. Any covariates that were significant at the $P<0.05$ level were included in all subsequent analyzed models as confounding factors. SPSS 16.0 was adopted to calculate the prevalence and to conduct multivariate regression models.

\section{Results}

\subsection{Study population and prevalence}

The survey recovered 2636 completed questionnaires with
$59 \%$ the response rate. A number of 2159 responses for children aged 3-6 years with 1159 boys (54\%) and 1000 girls $(46 \%)$ were used in this study.

The characteristics of the study population and the prevalence of allergic rhinitis in childhood according to the covariates were shown in Table 2. The overall prevalence of children's diagnosed allergic rhinitis was $8.4 \%$ (95\% CI: $7.0 \%-10.0 \%$ ). Higher prevalence was observed in children aged 6 than those aged 3. The prevalence for boys $9.2 \%$ (95\% CI: $8.0 \%-11.0 \%$ ) was relatively higher than that for girls $7.5 \%$ (95\% CI: $6.0 \%-9.0 \%$ ). The prevalence of children's allergic rhinitis was significantly positively associated with older children, family atopy, cockroaches noted, and flooding ever or water damage at home. A negative association was found for the duration of breast-feeding. The prevalence was also related to the presence of environmental tobacco smoking (ETS) and visible mould, although not significantly. Therefore, the main confounding factors related with the development of allergic rhinitis in the present study were considered as age, parental atopy, breast-feeding,

Table 2 Number of rhinitis cases, prevalence of diagnosed rhinitis, and odds ratios (ORs) of diagnosed rhinitis with $95 \%$ confidence interval (95\% CI) by age, sex, parental atopy, environmental tobacco smoke, breast-feeding, cockroaches, flooding or water damage, and visible mould ${ }^{\text {a) }}$

\begin{tabular}{|c|c|c|c|c|}
\hline Determinant & Number of children & $\begin{array}{c}\text { Number with } \\
\text { diagnosed rhinitis }\end{array}$ & Prevalence (\%) & OR $(95 \% \mathrm{CI})$ \\
\hline Total & 2159 & 182 & $8.4(7.0-10.0)$ & \\
\hline \multicolumn{5}{|l|}{ Age (years) } \\
\hline 3 & 556 & 34 & $6.1(4.0-8.0)$ & $0.468(0.250-0.877)$ \\
\hline 4 & 772 & 70 & $9.1(7.0-11.0)$ & $0.717(0.402-1.277)$ \\
\hline 5 & 700 & 62 & $8.9(7.0-11.0)$ & $0.698(0.389-1.253)$ \\
\hline 6 & 131 & 16 & $12.2(7.0-18.0)$ & 1.000 \\
\hline \multicolumn{5}{|l|}{ Sex } \\
\hline Male & 1159 & 107 & $9.2(8.0-11.0)$ & $1.254(0.922-1.707)$ \\
\hline Female & 1000 & 75 & $7.5(6.0-9.0)$ & 1.000 \\
\hline \multicolumn{5}{|l|}{ Parental atopy* } \\
\hline No & 1772 & 95 & $5.7(5.0-7.0)$ & 1.000 \\
\hline Yes & 335 & 84 & $26.2(21.0-31.0)$ & $5.907(4.259-8.191)$ \\
\hline \multicolumn{5}{|l|}{ ETS* } \\
\hline No & 750 & 57 & $7.6(6.0-10.0)$ & 1.000 \\
\hline Yes & 1383 & 125 & $9.0(8.0-11.0)$ & $1.208(0.871-1.675)$ \\
\hline \multicolumn{5}{|l|}{ Breast-feeding* } \\
\hline No & 188 & 23 & $12.2(8.0-17.0)$ & 1.000 \\
\hline$<3$ months & 280 & 26 & $9.3(6.0-13.0)$ & $0.734(0.405-1.330)$ \\
\hline $3-6$ months & 443 & 45 & $10.2(7.0-13.0)$ & $0.811(0.475-1.384)$ \\
\hline$>6$ months & 1207 & 84 & $7.0(6.0-8.0)$ & $0.537(0.329-0.875)$ \\
\hline \multicolumn{5}{|l|}{ Cockroaches noted $*$} \\
\hline No & 802 & 54 & $6.7(5.0-8.0)$ & 1.000 \\
\hline Yes & 1243 & 122 & $9.8(8.0-11.0)$ & $1.508(1.080-2.104)$ \\
\hline \multicolumn{5}{|l|}{ Water damage* } \\
\hline No & 1830 & 145 & $7.9(7.0-9.0)$ & 1.000 \\
\hline Yes & 207 & 29 & $14.0(9.0-19.0)$ & $1.893(1.235-2.903)$ \\
\hline \multicolumn{5}{|l|}{ Visible mould* } \\
\hline No & 1908 & 153 & $8.0(7.0-9.0)$ & 1.000 \\
\hline Yes & 140 & 15 & $10.7(6.0-16.0)$ & $1.376(0.786-2.411)$ \\
\hline
\end{tabular}

a) *Number of subjects can not add up to total $N$ because of missing data. Values in bold are indicated as $P<0.05$. 
cockroaches noted, and flooding or water damage.

\subsection{Air pollution and allergic rhinitis}

The distributions of annual average background and agerelated personal accumulative exposure of air pollutants including $\mathrm{PM}_{10}, \mathrm{SO}_{2}$ and $\mathrm{NO}_{2}$ were presented in Table 3 .

For the site-specific average background exposures, the average annual concentrations of $\mathrm{PM}_{10}, \mathrm{SO}_{2}$ and $\mathrm{NO}_{2}$ were 91.71, 49.63 and $46.87 \mu \mathrm{g} / \mathrm{m}^{3}$, respectively. All the levels of three air pollutants were significantly different among dif- ferent monitoring stations $(P<0.001$ in $T$-test). For the agerelated personal accumulative exposures, the older children exposed to the higher levels.

Table 4 showed the associations between the prevalence of childhood rhinitis and average site-specific background levels of air pollutants and age-related personal accumulative exposure by using multivariate logistic regression models. Children's diagnosed allergic rhinitis was not statistically significantly associated with average background concentrations of the three pollutants, but significantly related with age-related personal accumulative exposure of

Table 3 Mean and distribution of annual average and personal exposure of ambient air pollution for children with different ages in Changsha

\begin{tabular}{|c|c|c|c|c|c|c|}
\hline & Mean (SD) & Minimum & 25 th percentile & Median & 75th percentile & Maximum \\
\hline \multicolumn{7}{|c|}{ Site-specific background air pollution during 2007-2011 } \\
\hline $\mathrm{PM}_{10}$ & $91.71(4.21)$ & 87.48 & 87.64 & 92.12 & 95.57 & 97.52 \\
\hline $\mathrm{SO}_{2}$ & $49.63(10.32)$ & 34.08 & 41.53 & 50.07 & 57.50 & 62.97 \\
\hline $\mathrm{NO}_{2}$ & $46.87(7.81)$ & 40.45 & 41.60 & 43.91 & 52.12 & 59.99 \\
\hline \multicolumn{7}{|c|}{ Age-related accumulative personal exposure of air pollution } \\
\hline \multicolumn{7}{|l|}{3 years } \\
\hline $\mathrm{PM}_{10}$ & $257.01(18.88)$ & 237.55 & 239.37 & 254.74 & 275.78 & 282.36 \\
\hline $\mathrm{SO}_{2}$ & 122.35 (27.59) & 86.36 & 95.42 & 125.73 & 147.59 & 156.08 \\
\hline $\mathrm{NO}_{2}$ & $140.59(22.05)$ & 128.77 & 129.19 & 131.42 & 156.58 & 179.91 \\
\hline \multicolumn{7}{|l|}{4 years } \\
\hline $\mathrm{PM}_{10}$ & $352.79(23.54)$ & 330.71 & 331.08 & 351.29 & 375.24 & 386.72 \\
\hline $\mathrm{SO}_{2}$ & $177.95(37.06)$ & 124.24 & 145.69 & 180.36 & 209.00 & 225.70 \\
\hline $\mathrm{NO}_{2}$ & $186.01(30.07)$ & 166.02 & 168.90 & 176.11 & 208.06 & 239.25 \\
\hline \multicolumn{7}{|l|}{5 years } \\
\hline $\mathrm{PM}_{10}$ & $458.53(21.05)$ & 437.42 & 438.18 & 460.59 & 477.86 & 487.62 \\
\hline $\mathrm{SO}_{2}$ & $248.14(51.06)$ & 170.40 & 207.66 & 250.33 & 287.52 & 314.83 \\
\hline $\mathrm{NO}_{2}$ & 231.35 (39.06) & 202.23 & 208.02 & 219.53 & 260.60 & 299.95 \\
\hline \multicolumn{7}{|l|}{6 years } \\
\hline $\mathrm{PM}_{10}$ & $569.18(15.12)$ & 553.64 & 554.03 & 570.67 & 583.58 & 587.97 \\
\hline $\mathrm{SO}_{2}$ & 335.35 (85.10) & 219.04 & 271.66 & 325.72 & 403.86 & 457.88 \\
\hline $\mathrm{NO}_{2}$ & $272.50(47.33)$ & 237.72 & 246.22 & 254.92 & 307.57 & 355.88 \\
\hline
\end{tabular}

Table 4

Adjusted odds ratios (ORs) and 95\% confidence interval (CIs) of physician diagnosed rhinitis in single and two-pollutant models ${ }^{\text {a) }}$

\begin{tabular}{|c|c|c|c|}
\hline & Single-pollutant model & $\begin{array}{c}\text { Two-pollutant model } \\
1\left(\mathrm{PM}_{10}+\mathrm{SO}_{2}\right)\end{array}$ & $\begin{array}{c}\text { Two-pollutant model } \\
2\left(\mathrm{PM}_{10}+\mathrm{NO}_{2}\right)\end{array}$ \\
\hline \multicolumn{4}{|c|}{ Site-specific background air pollutants } \\
\hline $\mathrm{PM}_{10}\left(\right.$ per $\left.10 \mu \mathrm{g} / \mathrm{m}^{3}\right)$ & $1.074(0.710-1.627)$ & $1.343(0.592-3.044)$ & $0.891(0.465-1.708)$ \\
\hline $\mathrm{SO}_{2}\left(\right.$ per $\left.10 \mu \mathrm{g} / \mathrm{m}^{3}\right)$ & $0.997(0.843-1.179)$ & $0.901(0.650-1.249)$ & \\
\hline $\mathrm{NO}_{2}\left(\right.$ per $\left.10 \mu \mathrm{g} / \mathrm{m}^{3}\right)$ & $1.083(0.875-1.340)$ & & $1.134(0.808-1.594)$ \\
\hline \multicolumn{4}{|c|}{ Age-related accumulative exposure of air pollutants } \\
\hline $\mathrm{SO}_{2}\left(\right.$ per $\left.10 \mu \mathrm{g} / \mathrm{m}^{3}\right)$ & $1.026(1.005-1.048)$ & $1.018(0.972-1.066)$ & \\
\hline $\mathrm{NO}_{2}\left(\right.$ per $\left.10 \mu \mathrm{g} / \mathrm{m}^{3}\right)$ & $1.037(1.006-1.069)$ & & $1.025(0.963-1.090)$ \\
\hline
\end{tabular}

a) Logistic regression models for site-specific background air pollutants adjusting for age, parental atopy, breast-feeding, cockroaches noted and flooding or water damage, while age was not adjusted for the models for age-related accumulative exposure of air pollutants. Values in bold are indicated as $P<0.05$. 
$\mathrm{PM}_{10}, \mathrm{SO}_{2}$ and $\mathrm{NO}_{2}$. In the one-pollutant model, age-related personal accumulative exposure of $\mathrm{PM}_{10}, \mathrm{SO}_{2}$ and $\mathrm{NO}_{2}$ were significantly positively associated with allergic rhinitis. An increase of $10 \mu \mathrm{g} / \mathrm{m}^{3}$ in age-related personal accumulative exposure to $\mathrm{PM}_{10}, \mathrm{SO}_{2}$ and $\mathrm{NO}_{2}$ may lead to an increase in the prevalence of children's rhinitis by $2.1 \%(95 \% \mathrm{CI}$, $0.3 \%-3.9 \%), 2.6 \%$ (95\% CI, $0.5 \%-4.8 \%$ ) and $3.7 \%$ (95\% CI, 0.6\%-6.9\%), respectively. Among these three pollutants, $\mathrm{NO}_{2}$ indicated a higher risk in rhinitis than $\mathrm{PM}_{10}$ and $\mathrm{SO}_{2}$. In the two-pollutant model, no significant estimate effect was observed when added to either of two air pollutants. Therefore, the risk of children's rhinitis was significantly associated with age-related personal accumulative exposure of single air pollutant.

To further explore whether the main covariates mentioned in Table 2 aggravate the effect of air pollutant on the rhinitis prevalence, stratified analyses were systematically conducted for age-related personal accumulative exposure of air pollutants by different categories of gender, parental atopy, duration of breast-feeding, cockroaches noted and water damage. The results indicated that exposure to air pollution has significantly higher risk for males, children having breast-feeding less than 3 months, and those living in the home with water damage (Table 5).

\section{Discussion}

\subsection{Effects of household and personal characteristics}

We found that certain residential, demographic, and housing characteristics were associated with the prevalence of rhinitis in children aged 3-6 in Changsha. Main risk factors included parental atopy, the shortage of breast-feeding, cockroaches, and water damage in the home. Most of these risk factors identified in the present study have been found in previous questionnaire assessments of children living in different climates and exposure to different air pollution. In a crosssectional study in Taiwan, China, a significantly increased risk of rhinitis was found to be related to parental atopy [8]. The study by Åberg et al. [25] also showed that the family history of the diseases was the strongest background factor for the development of children's asthma and allergic diseases. In addition, the study by Hwang et al. [8] showed a significant effect of home dampness (or more specifically, water damage, and mold or mildew-derived allergens) on children's diagnosed rhinitis. Similar effects of dampness on both diagnosed rhinitis and ever related symptoms in middle-school children were observed in Taiwan, China [7]. In our study, shortage of breast-feeding and cockroaches in the home also showed a significant effect on the preschool children's rhinitis.

The overall consistency between our results and previous findings suggests that most or all of the known personal and household risk factors operate over a considerable range of population and environmental characteristics [26]. On the basis of this evidence, broad-based campaign to abate airborne hazards inside homes, including specific allergens from cockroaches and dampness-dependent organisms, would be an effective intervention on behalf of children's respiratory health.

Table 5 Adjusted odds ratios (ORs) along with 95\% confidence interval (CIs) of diagnosed rhinitis stratified by different levels of covariates in the relation between diagnosed rhinitis and age-related personal accumulative exposure of air pollutants per $10 \mu \mathrm{g} / \mathrm{m}^{3}$ increase

\begin{tabular}{|c|c|c|c|c|c|c|c|c|c|c|}
\hline & Gender & OR $(95 \% \mathrm{CI})^{\mathrm{a}}$ & $\begin{array}{c}\text { Parental } \\
\text { atopy }\end{array}$ & OR $(95 \% \mathrm{CI})^{\mathrm{a})}$ & $\begin{array}{l}\text { Breast } \\
\text { feeding }\end{array}$ & OR $(95 \% \mathrm{CI})^{\mathrm{a})}$ & $\begin{array}{c}\text { Cockroaches } \\
\text { noted }\end{array}$ & OR $(95 \% \text { CI })^{\text {a) }}$ & $\begin{array}{c}\text { Water } \\
\text { damage }\end{array}$ & OR $(95 \% \mathrm{CI})^{\mathrm{a})}$ \\
\hline \multirow{4}{*}{$\mathrm{PM}_{10}$} & Male & $\begin{array}{l}1.025 \\
(1.002-1.049)\end{array}$ & Yes & $\begin{array}{l}1.023 \\
(0.992-1.055)\end{array}$ & No & $\begin{array}{l}1.015 \\
(0.965-1.067)\end{array}$ & Yes & $\begin{array}{l}1.020 \\
(0.998-1.043)\end{array}$ & Yes & $\begin{array}{l}1.059 \\
(1.008-1.112)\end{array}$ \\
\hline & Female & $\begin{array}{l}1.011 \\
(0.982-1.041)\end{array}$ & No & $\begin{array}{l}1.020 \\
(0.997-1.043)\end{array}$ & $<3$ months & $\begin{array}{l}1.047 \\
(1.001-1.095)\end{array}$ & No & $\begin{array}{l}1.023 \\
(0.991-1.056)\end{array}$ & No & $\begin{array}{l}1.015 \\
(0.995-1.035)\end{array}$ \\
\hline & & & & & $3-6$ months & $\begin{array}{l}1.035 \\
(0.997-1.074)\end{array}$ & & & & \\
\hline & & & & & $>6$ months & $\begin{array}{l}1.008 \\
(0.981-1.036)\end{array}$ & & & & \\
\hline \multirow{4}{*}{$\mathrm{SO}_{2}$} & Male & $\begin{array}{l}1.035 \\
(1.009-1.062)\end{array}$ & Yes & $\begin{array}{l}1.033 \\
(0.995-1.072)\end{array}$ & No & $\begin{array}{l}1.027 \\
(0.971-1.087)\end{array}$ & Yes & $\begin{array}{l}1.024 \\
(0.997-1.051)\end{array}$ & Yes & $\begin{array}{l}1.056 \\
(1.000-1.114)\end{array}$ \\
\hline & Female & $\begin{array}{l}1.006 \\
(0.970-1.044)\end{array}$ & No & $\begin{array}{l}1.022 \\
(0.996-1.049)\end{array}$ & $<3$ months & $\begin{array}{l}1.062 \\
(1.012-1.115)\end{array}$ & No & $\begin{array}{l}1.029 \\
(0.991-1.068)\end{array}$ & No & $\begin{array}{l}1.021 \\
(0.997-1.045)\end{array}$ \\
\hline & & & & & $3-6$ months & $\begin{array}{l}1.026 \\
(0.981-1.074)\end{array}$ & & & & \\
\hline & & & & & $>6$ months & $\begin{array}{l}1.013 \\
(0.980-1.046)\end{array}$ & & & & \\
\hline \multirow{4}{*}{$\mathrm{NO}_{2}$} & Male & $\begin{array}{l}1.050 \\
(1.010-1.091)\end{array}$ & Yes & $\begin{array}{l}1.043 \\
(0.990-1.098)\end{array}$ & No & $\begin{array}{l}1.063 \\
(0.977-1.157)\end{array}$ & Yes & $\begin{array}{l}1.032 \\
(0.994-1.070)\end{array}$ & Yes & $\begin{array}{l}1.103 \\
(1.018-1.196)\end{array}$ \\
\hline & Female & $\begin{array}{l}1.012 \\
(0.963-1.064)\end{array}$ & No & $\begin{array}{l}1.035 \\
(0.996-1.074)\end{array}$ & $<3$ months & $\begin{array}{l}1.081 \\
(1.008-1.159)\end{array}$ & No & $\begin{array}{l}1.050 \\
(0.993-1.109)\end{array}$ & No & $\begin{array}{l}1.028 \\
(0.994-1.063)\end{array}$ \\
\hline & & & & & $3-6$ months & $\begin{array}{l}1.042 \\
(0.978-1.110)\end{array}$ & & & & \\
\hline & & & & & $>6$ months & $\begin{array}{l}1.016 \\
(0.969-1.064)\end{array}$ & & & & \\
\hline
\end{tabular}

a) Logistic regression adjusting for other covariates. Values in bold are indicated as $P<0.05$. 


\subsection{Effects of ambient air pollution}

In the present study, the prevalence of allergic rhinitis in children aged 3-6 years was significantly positively associated with age-related personal accumulative exposure levels of $\mathrm{PM}_{10}, \mathrm{SO}_{2}$ and $\mathrm{NO}_{2}$, but not with site-specific average background exposures (Table 4). And the results provided evidence that males, breast-feeding less than 3 months, and water damage in the home could aggravate the effect of age-related personal accumulative exposure to air pollutants on allergic rhinitis in children (Table 5).

For site-specific average background exposure, our results were consistent with some previous studies. In French ISAAC study, no association was observed between prevalence of allergic rhinitis and mean concentrations of both $\mathrm{SO}_{2}$ and $\mathrm{NO}_{2}$ [10]. Guo et al. [27] and Lee et al. [7] found no significant association between prevalence of lifetime allergic rhinitis and fossil fuel combustion related air pollutants (namely $\mathrm{SO}_{2}$ and $\mathrm{PM}_{10}$ ). A prospective birth cohort study [11] assessed the relationship between individualbased exposure to traffic-related air pollutants and allergic diseases outcomes during the first 6 years of life, and they also found no association between $\mathrm{NO}_{2}$ exposure and allergic sensitization. One possible reason for the lack of association may be due to the low concentration of air pollutants, the average values of $\mathrm{PM}_{10}, \mathrm{SO}_{2}$ and $\mathrm{NO}_{2}$ in these studies ranging from 34.9-69.2, 17.3-57.4 and 20.3-51.3 $\mu \mathrm{g} / \mathrm{m}^{3}$, respectively. However, no significant effect was also obtained in the present study, although the background exposure levels of $\mathrm{PM}_{10}, \mathrm{SO}_{2}$ and $\mathrm{NO}_{2}$ were high up to 91.71, 49.63 and $46.87 \mu \mathrm{g} / \mathrm{m}^{3}$, respectively. These results suggested that the concentration may not be the only factor which affects AR. On the other hand, some recent studies have found that traffic-related pollutants were closely associated with AR. The references [29,30] reported positive correlation between traffic density and the prevalence of AR. Weiland et al. [30] also suggested a possible role of factors associated with automobile exhausts in children's AR. Hwang et al. [8] investigated the relationship between trafficrelated air pollutants and allergic rhinitis in middle-school students in Taiwan, China, and found significant associations for traffic-related air pollutants (e.g. $\mathrm{CO}, \mathrm{NO}_{x}$ and $\mathrm{O}_{3}$ ) in both sexes but none for $\mathrm{SO}_{2}$ and $\mathrm{PM}_{10}$. These results indicated that both concentration and source type of the air pollution may contribute to the development of AR.

However, all above studies addressed the same average background concentration on all the children with different ages. In the present study, we not only investigated the site-specific average background air pollution, but also considered the age-related personal accumulative exposure. Based on our data, the site-specific background exposures of $\mathrm{PM}_{10}, \mathrm{SO}_{2}$ and $\mathrm{NO}_{2}$ were not associated with $\mathrm{AR}$, but significant effects were observed for age-related personal accumulative exposure to each of these air pollutants. Our result indicates that the timing for exposure to air pollution is important to the development of childhood's AR. For example, a significantly higher prevalence of rhinitis was found in the children aged 6 years $12.2 \%(95 \% \mathrm{CI}, 7.0 \%-$ $18.0 \%$ ) than those aged 3 years $6.1 \%$ (95\% CI $4.0 \%-8.0 \%$ ) (Table 2).

\subsection{Limitation}

In the present study, the exposure to the air pollution for each kindergarten was determined by the data from the nearest monitoring station. Due to the similar sources and strength of air pollution, we assumed that the individual exposure could be characterized by the adjacent exposure in the same community. Actually, it is not the exact personal exposures, which may lead to some errors in the results. In addition, children are actually exposed to both kindergarten and home environments, but the present study only considered the exposures at kindergartens. Although previous study suggested that exposure at locations other than home, especially at school or kindergarten where children spent a large proportion of waking hours and engaging in physical activity may have strong influences on occurrence of respiratory diseases [31], the effect of exposure at home environment may not be ignored. Therefore, the mixed effects of exposure to air pollutants both at kindergarten and home environments on children's AR or other allergies need to be further investigated.

\section{Conclusions}

The present study assessed the prevalence of diagnosed allergic rhinitis in children aged 3-6 years in Changsha, and investigated the relationship between allergic rhinitis and both site-specific average background and age-related personal accumulative exposures to ambient air pollutants including $\mathrm{PM}_{10}, \mathrm{SO}_{2}$ and $\mathrm{NO}_{2}$. The main conclusions of this study are as follows:

(1) The prevalence of allergic rhinitis in children aged 3-6 in Changsha were $8.4 \%$ (95\% CI, 7.0\%-10.0\%). Boys had a higher morbidity with $9.2 \%(95 \% \mathrm{CI}: 8.0 \%-11.0 \%)$ than that for girls with the value of $7.5 \%$ (95\% CI: $6.0 \%-$ $9.0 \%)$.

(2) Age-related personal accumulative exposure of $\mathrm{PM}_{10}$, $\mathrm{SO}_{2}$ and $\mathrm{NO}_{2}$ may play an important role in the development of preschool children's allergic rhinitis, and trafficrelated pollutant $\mathrm{NO}_{2}$ has a relatively higher risk than $\mathrm{PM}_{10}$ and $\mathrm{SO}_{2}$. However, no effect was found for site-specific average background exposures.

(3) Long-term exposure to high concentration level of ambient air pollution may be more likely to develop preschool children's allergic rhinitis.

This work was supported by the National Natural Science Foundation of China (51178466) and the Research Fund for the Doctoral Program of 
Higher Education of China (20120162110011). We appreciate for the help and contributions from the teachers and the students who were responsible for the distribution and data of the questionnaires. We also thanks for the cooperation of the leaders and teachers in the kindergartens and the participation of the parents.

1 Bousquet J, Khaltaev N, Cruz A A, et al. Allergic rhinitis and its impact on asthma (ARIA) 2008. Allergy, 2008, 63(Suppl 86): 8-160

2 Katelaris C H, Lee B W, Potter P C, et al. Prevalence and diversity of allergic rhinitis in regions of the world beyond Europe and North America. Clin Exp Allergy, 2012, 42: 186-207

3 Lee S L, Wong W, Lau Y L. Increasing prevalence of allergic rhinitis but not asthma among children in Hong Kong from 1995 to 2001 (Phase 3 International Study of Asthma and Allergies in Childhood). Pediatr Allergy Immunol, 2004, 15: 72-78

4 Asher M I, Montefort S, Björkstén B, et al. Worldwide time trends in the prevalence of symptoms of asthma, allergic rhinoconjunctivitis, and eczema in childhood: ISAAC Phases one and three repeat multicountry cross-sectional surveys. Lancet, 2006, 368: 733-743

5 Kong W J, Chen J J, Zheng Z Y, et al. Prevalence of allergic rhinitis in 3-6-year-old children in Wuhan of China. Clin Exp Allergy, 2009, 39: 869-874

6 Krämer U, Koch T, Ranft U, et al. Traffic-related air pollution is associated with atopy in children living in urban areas. Epidemiology, 2000, 11: 64-70

7 Lee Y L, Shaw C K, Su H J, et al. Climate, traffic-related air pollutants and allergic rhinitis prevalence in middle-school children in Taiwan. Eur Respir J, 2003, 21: 964-970

8 Hwang B F, Jaakkola J J K, Lee Y L, et al. Relation between air pollution and allergic rhinitis in Taiwanese schoolchildren. Respir Res, 2006, 7: 23-29

9 Hajat S, Haines A, Atkinson R W, et al. Association between air pollution and daily consultations with general practitioners for allergic rhinitis in London, United Kingdom. Am J Epidemiol, 2001, 153: 704-714

10 Ramadour M, Burel C, Lanteaume A, et al. Prevalence of asthma and rhinitis in relation to long-term exposure to gaseous air pollutants. Allergy, 2000, 55: 1163-1169

11 Morgenstern V, Zutavern A, Cyrys J, et al. Atopic diseases, allergic sensitization, and exposure to traffic-related air pollution in children. Am J Respir Crit Care Med, 2008, 177: 1331-1337

12 Charpin D, Pascal L, Birnbaum J, et al. Gaseous air pollution and atopy. Clin Exp Allergy, 1999, 29: 1474-1480

13 von Mutius E, Sherrill D L, Fritzsch C, et al. Air pollution and upper respiratory symptom in children from East Germany. Eur Respir J, 1995, 8: 723-728

14 Chitano P, Hosselet J J, Mapp C E, et al. Effect of oxidant air pollutants on the respiratory system: insights from experimental animal research. Eur Respir J, 1995, 8: 1357-1371

15 Kampa M, Castanas E. Human health effects of air pollution. Environ Pollut, 2008, 151: 362-367
16 Pope III C A, Dockery D W, Spengler J D, et al. Respiratory health and $\mathrm{PM}_{10}$ pollution: A daily time series analysis. Am J Respir Crit Care Med, 1991, 144: 668-674

17 Chauhan A J, Krishna M T, Frew A J, et al. Exposure to nitrogen dioxide $\left(\mathrm{NO}_{2}\right)$ and respiratory disease risk. Rev Environ Health, 1998, 13: 73-90

18 Studnicka M, Hackl E, Pischinger J, et al. Traffic-related $\mathrm{NO}_{2}$ and the prevalence of asthma and respiratory symptoms in seven year olds. Eur Respir J, 1997, 10: 2275-2278

19 Brauer M, Hoek G, van Vliet P, et al. Air pollution from traffic and the development of respiratory infections and asthmatic and allergic symptoms in children. Am J Respir Crit Care Med, 2002, 166: 10921098

20 Zhang Q, Geng G N, Wang S W, et al. Satellite remote sensing of changes in $\mathrm{NO}_{x}$ emissions over China during 1996-2010. Chin Sci Bull, 2012, 57: 2857-2864

21 Yang T, Wang Z F, Zhang B, et al. Evaluation of the effect of air pollution control during the Beijing 2008 Olympic Games using Lidar data. Chin Sci Bull, 2010, 55: 1311-1316

22 Naydenov K, Melikov A, Markov D, et al. A comparison between occupants' and inspectors' reports on home dampness and their association with the health of children: The ALLHOME study. Build Environ, 2008, 43: 1840-1849

23 Tham K W, Zuraimi M S, Koh D, et al. Associations between home dampness and presence of molds with asthma and allergic symptoms among young children in the tropics. Pediatr Allergy Immunol, 2007, 18: $418-424$

24 Down S H, Schindler C, Liu L J S, et al. Reduced exposure to $\mathrm{PM}_{10}$ and attenuated age-related decline in lung function. N Engl J Med, 2007, 357: 2338-2347

25 Åberg N, Sundell J, Eriksson B, et al. Prevalence of allergic diseases in schoolchildren in relation to family history, upper respiratory infections, and residential characteristics. Allergy, 1996, 51: 232-237

26 Peters J M, Avol E, Navidi W, et al. A study of twelve southern California communities with differing levels and types of air pollution I. Prevalence of respiratory morbidity. Am J Respir Crit Care Med, 1999, 159: 760-767

27 Guo Y L, Lin Y C, Sung F C, et al. Climate, traffic-related air pollutants, and asthma prevalence in middle-school children in Taiwan. Environ Health Perspect, 1999, 107: 1001-1006

28 Duhme H, Weiland S K, Keil U, et al. The association between selfreported symptoms of asthma and allergic rhinitis and self-reported traffic density on street of residence in adolescents. Epidemiology, 1996, 7: 578-582

29 Ciccone G, Forastiere F, Agabiti N, et al. Road traffic and adverse respiratory effects in children. Occup Environ Med, 1998, 55: 771-778

30 Weiland S K, Mundt K A, Rückmann A, et al. Self-reported wheezing and allergic rhinitis in children and traffic density on street of residence. Ann Epidemiol, 1994, 4: 243-247

31 McConnell R, Islam T, Shankardass K, et al. Childhood incident asthma and traffic-related air pollution at home and school. Environ Health Perspect, 2010, 118: 1021-1026

Open Access This article is distributed under the terms of the Creative Commons Attribution License which permits any use, distribution, and reproduction in any medium, provided the original author(s) and source are credited. 